\title{
Current Status of Laparoscopic Therapy of Cholecystolithiasis and Common Bile Duct Stones
}

\author{
Andreas Shamiyeh Wolfgang Wayand \\ Ludwig Boltzmann Institute for Operative Laparoscopy and Second Surgical Department, Academic Teaching \\ Hospital, Linz, Austria
}

\author{
Key Words \\ Laparoscopy $\cdot$ Cholecystectomy $\cdot$ Cholecystitis • \\ Common bile duct stones
}

\begin{abstract}
Background: Laparoscopic cholecystectomy (LC) is the standard operation for gallstone disease. The aim of this review was to scrutinize the advantages and benefits of this minimal invasive technique compared to the conventional operation according to the available literature. Regarding the evidence-based medicine criteria, the current status of laparoscopy in the treatment of cholecystolithiasis, cholecystitis and common bile duct stones has been worked out. Methods: A Medline, PubMed, Cochrane search. Results: Ten randomized controlled trials (RCTs) are available comparing laparoscopic versus open cholecystectomy. The superiority of LC in less postoperative pain, shorter recovery and hospital stay is stated. Operation time was longer in the first years of LC. 3 RCTs deal with acute cholecystitis: one paper could not find any significant advantage of LC over conventional cholecystectomy, the other two found benefits in recovery, hospital stay and postoperative pain. The range of conversion is between 5 and $7 \%$ in elective cases and increases up to $27 \%$ for acute cholecystitis. With a rate of more than $90 \%$ in Europe, the standard procedure for common bile duct stones is 'therapeutic splitting' with
\end{abstract}

endoscopy and retrograde cholangiopancreatography preoperatively followed by LC. Laparoscopic bile duct clearance is effective and safe in experienced hands, however, the only proven benefit is a slightly shorter hospital stay. Conclusion: The laparoscopic approach is preferred in elective cholecystectomy and acute cholecystitis. The minimal invasive technique has proven to be effective, gentle and safe. The main benefits are evident within the first postoperative days.

Copyright (C) 2005 S. Karger AG, Basel

\section{Introduction}

Gallstone disease has a great impact on a surgeon's daily routine. The prevalence rate of cholecystolithiasis is $10-12 \%$ in the Western world and about $3-4 \%$ in Asian populations [1]. The costs for the treatment of biliary stone disease in the prelaparoscopic area were estimated at USD 16 billion in the USA in 1987 [2], about 1 million people are newly diagnosed annually in the USA [3], and approximately 600,000 operations are performed every year.

Laparoscopy has changed the treatment of symptomatic cholecystolithiasis worldwide. After the initial experience of Mühe [4], Mouret [5] performed the first laparoscopic cholecystectomy (LC) in Europe in 1987 by use of a pneumoperitoneum. Over the last decade, numerous

\section{KARGER}

Fax +4161306 1234 E-Mail karger@karger.ch www.karger.com
(C) $2005 \mathrm{~S}$. Karger AG, Basel

0257-2753/05/0232-0119\$22.00/0

Accessible online at: www.karger.com/ddi
Andreas Shamiyeh

Ludwig Boltzmann Institute for Operative Laparoscopy

Second Surgical Department, Academic Teaching Hospital

Krankenhausstrasse 9, AT-4020 Linz (Austria)

Tel. +43 7327806 2133, Fax +437327806 2198, E-Mail andreas.shamiyeh@akh.linz.at 
trials and reviews could show the superiority of LC over open cholecystectomy, and LC developed as the standard procedure for biliary disease and was first called the 'gold standard' in 1989 [6]. However, with the new technique, not only the management of gallstone disease has changed, but also the spectrum of complications [7]. The benefits of LC are well documented and will be discussed later on, but a few questions remain unanswered so far: Is the 'learning curve' avoidable? What is the best treatment for common bile duct stones? How are lost gallstones best treated?

In this article, LC is discussed according to the available literature in order to underline the current status of laparoscopic therapy of cholecystolithiasis and common bile duct stones.

\section{Methods}

Literature review: an electronic search of the Medline and PubMed databases and the Cochran library was conducted using the following key words: laparoscopic cholecystectomy, cholecystectomy, common bile duct, common bile duct stones, endoscopy and retrograde cholangiopancreatography (ERCP), and endoscopic sphincterotomy. Relevant articles were achieved and cited.

\section{Preoperative Assessment}

Abdominal ultrasound is undoubtedly the primary tool for the diagnosis of cholecystolithiasis. In combination with laboratory findings and an exact patient's history the correct diagnosis should be made. In the first years of LC, intravenous cholangiography (IVC) was used as a valuable tool for the imaging of the bile duct's anatomy in order to prevent common bile duct (CBD) injuries and to diagnose possible bile duct stones. IVC is entailed with possible adverse reactions [8] and after the initial experience of LC, IVC was considered not to be used as a routine screening modality preoperatively [9]. However, some authors think that IVC is underestimated and might be used routinely preoperatively [10]. There is also no need to explain that spiral CT cholangiography is not suitable for routine diagnosis before LC [11] as well as ERCP [12]. Magnetic resonance cholangiography has gained importance for the diagnosis of common bile duct stones (CBDS).

Routine gastroscopy prior to LC is still discussed controversially. In Germany the rate of routine gastroscopy is about $40 \%$ [13]. While authors claim it as a standard examination before LC, others do not [14-16]. However, it is most important to perform an adequate anamnesis and clinical examination. Then, endoscopy prior to cho- lecystectomy should be performed only in patients with a history of upper abdominal pain or discomfort [1719].

At the beginning of LC, patients were well selected in order to avoid complications. Previous operations as well as liver cirrhosis and portal hypertension are meant to be contraindications. Now, more than 15 years later, contraindications are rare.

\section{Technique}

$\mathrm{LC}$ is performed by use of a $\mathrm{CO}_{2}$ pneumoperitoneum. Reports of other gases are rare, they have no advantage over $\mathrm{CO}_{2}$, except $\mathrm{N}_{2} \mathrm{O}$ is discussed to have some role in cases of pulmonary dysfunction [20]. Warmed and humidified $\mathrm{CO}_{2}$ gas offers the patient postoperative advantages like less shoulder pain and less abdominal pain [21].

For patient positioning, two possibilities exist: either the French position with the surgeon between the patients' legs [22, 23] or the American position with the patient in the supine position with the surgeon standing on the left-hand side [24].

The closed access using the Veress needle is the most popular way to establish the pneumoperitoneum [25]. Another possibility is the open Hasson technique first described in 1973 [26] which is discussed to be safer, however, the advantage is contested [27]. Two randomized trials could not show any timesaving advantage over the access using the Veress needle $[28,29]$.

The dissection in Callot's triangle should be performed using the 'critical view' technique [30]: the only two identified structures entering the gallbladder can only be the duct and the artery, and have to be identified clearly before cutting them. These structures might be secured either by metallic or resorbable clips [31]. Bipolar electrocautery is not safe in the closure of the cystic duct [32, 33].

The dissection is usually done retrograde from the infundibulum to the fundus. In difficult situations the fundus-first technique seems to be safe [34-36].

There is no evidence recommending drainage routinely. One prospective randomized trial could not prove any advantage of a subphrenic placed drain in order to evacuate the residual $\mathrm{CO}_{2}$ gas [37].

\section{Intraoperative Cholangiography}

Whether to perform an intraoperative cholangiography (IOC) or not is still discussed controversially: argu- 
ments for the routine use are the detection of possible hidden stones in the CBD and to find possible anatomical variations [38-40]. Routine IOC is further applied if laparoscopic CBD clearance is favored. Secondly, IOC can be used only selectively [41-44].

Two randomized trials could not prove any advantage of routine IOC except for an increase of costs and time in the operating room $[45,46]$.

Finally, IOC might also be favored to avoid intraoperative CBD injuries. However, using IOC, a bile duct lesion might be detected earlier, but it does not prevent injury [47-49]. Metcalfe et al. [50] confirmed these results with a fine review on that topic. There is also no correlation between anatomical variations and CBD injuries $[51,52]$.

So far, IOC cannot be proclaimed as a routine 'must' during LC, but IOC must be available whenever LC is performed.

\section{Current Status of Laparoscopic Therapy of Cholecystolithiasis}

Excluding the randomized controlled trials (RCTs) involving acute cholecystitis and RCT 'early' vs. 'delayed' surgery, the trials regarding in- or outpatient surgery in 10 RCTs are available comparing LC vs. open cholecystectomy or minicholecystectomy (MC). MC is defined as open cholecystectomy through a laparotomy $<8 \mathrm{~cm}[53$, 54].

In the first years of LC the longer operation time was the most significant disadvantage of the minimal invasive approach. In the trial of Trondsen et al. [55] including patients from 1990 and 1991, LC took twice as long as operative cholangiography (OC), however, the hospital stay was half as long as in the open group. Most of the trials resulted in having a shorter hospital stay, less pain, faster return to normal activity resulting in less postoperative risk for pulmonary complications not only in healthy subjects but also in patients with cirrhotic portal hypertension [56-61]. However, the main advantages are only for the first days postoperatively. McMahon et al. [59] demonstrated that the benefits of LC diminish beginning after the first week to an equal state 3 months postoperatively.

With laparoscopy the management of patients changed, postoperative mobilization, feeding and discharge were accelerated. The surgeons, the staff and the patients adopted this strategy inevitably also to conventionally operated patients.

Laparoscopic Cholecystectomy
Majeed et al. [54] concluded in their RCT that LC takes longer to do than small-incision cholecystectomy and does not have any advantages in terms of hospital stay or postoperative recovery. These results were confirmed shortly afterwards in 1998 when Squirrell et al. [62] showed that the analgesic consumption, perceived health and postoperative stay are equal in both groups - LC vs. MC. This trial included 200 patients. Finally, there is a multicenter RCT from Sweden comparing LC with MC including 724 randomized patients. Their conclusion was a shorter sick leave and faster return to work after LC, an equal postoperative complication rate and lower intraoperative complication rate in the MC group. The operation time was longer for LC [63]. Syrakos et al. [53] confirmed these results in a retrospective study including more than 1,200 patients comparing LC vs. MC vs. OC. They encouraged the commissioners of healthcare to discuss whether the additional costs of LC are justified.

The overall rate of cholecystectomy by laparoscopy is about $75 \%$ in the western world: in the USA the rate of LC for chronic cholecystitis is $78 \%$ with a conversion rate of $6.1 \%$, in acute cholecystitis $77 \%$ (conversion rate $10 \%$ ) [64]. In Germany the overall rate is 71.9\% [65] and in Australia 75\% [66]. In our clinic, 5,376 patients underwent cholecystectomy from 1990 till December 1993, $84 \%$ laparoscopically, $10.8 \%$ primarily open, and $4.8 \%$ had to be converted.

\section{Current Status of Laparoscopic Therapy for Acute Cholecystitis}

About $1-3 \%$ of all patients with symptomatic gallstone disease develop acute cholecystitis [67]. 10-30\% of patients with acute cholecystitis develop severe complications like empyema, gangrene or perforation [68-70]. Women develop calculous cholecystitis three times more often than men up to the age of 50 years [71]. The main cause of the acute inflammation is the obstruction of the cystic duct by a gallstone followed by a chemical and/or bacterial inflammatory reaction. In eastern countries, the reason number one are parasites [72].

The definition of cholecystitis was differently interpreted in the literature. Min et al. [73] defined it if two or more of the clinical and operative findings were positive: fever $>37.5^{\circ} \mathrm{C}$, right upper abdominal pain with tenderness $>48 \mathrm{~h}$, gallbladder wall $>4 \mathrm{~mm}$, adhesion to an adjacent organ and inflammation of the gallbladder serosa [74]. Cameron [75] defined it as right upper quadrant

Dig Dis 2005;23:119-126 
pain for $>12 \mathrm{~h}$, a raised white cell count and findings consistent with acute cholecystitis on ultrasound.

The value of cholecystectomy in acute cholecystitis has already been proven in the prelaparoscopic area [76, 77], however, there is one RCT comparing delayed LC vs. observation [71]. Vetrhus et al. [78] compared 31 vs. 33 patients with regard to the natural sequel of cholecystitis without surgical treatment. $30 \%$ had to be operated within the follow-up period of 60 months. They concluded that there is a certain risk of suffering from gallstone-related complications following conservative treatment, but cholecystectomy should not necessarily be compulsory after acute cholecystitis.

After the introduction of laparoscopy, two questions gained interest in the treatment of acute cholecystitis: Is LC superior to OC and is early LC prior to delayed LC? Early LC is defined as treatment within the first $48-72 \mathrm{~h}$ after the onset of symptoms.

$L C$ vs. OC: There is no systemic review but 3 RCTs. In the most recent study by Johansson et al. [79], neither the patients nor the hospital staff were informed about the type of operation. The operation time was slightly shorter in the laparoscopic group $(\mathrm{p}=0.04)$ but the hospital stay was significantly longer $(p=0.01) .14$ patients out of 35 operated conventionally thought that they had been operated laparoscopically. To achieve such results it is very important to follow exactly the same regimen postoperatively for both groups. They concluded that there is no relevant clinical difference in the postoperative outcome after LC or OC in the treatment of acute cholecystitis.

The other two RCTs could show that LC provided less postoperative pain and a shorter hospital stay. The conversion rate was 27 and 16\%, respectively [69, 80].

Finally, there is one RCT comparing mini-LC vs. LC using 2- and 3-mm instruments [81]. They found similar results in both groups.

Early vs. Delayed LC: Three RCTs: Lai et al. [82] demonstrated no difference in the conversion rate in both groups ( $21 \%$ early vs. $24 \%$ delayed). Delayed operation was defined after an interval of 6-8 weeks. $16 \%$ had to be operated earlier than scheduled due to recurrent symptoms. $10 \%$ had no operation at all due to successful conservative treatment. In the second RCT by Lo et al. [83], conversion was necessary in $11 \%$ of the early and $23 \%$ of the delayed group and $19.5 \%$ had to be operated before a planned interval of 6 weeks. The morbidity was equal in both trials for both groups and the hospital stay was short- er in the early group. Johansson et al. [84] found similar results in their trial in 2003 - conversion rate (31 vs. $29 \%$ ), morbidity and operation times were comparable however, and $26 \%$ of the delayed group had to be operated earlier. The hospital stay was shorter in the early group. In another prospective trial, the conservative treatment failed completely in $14.3 \%$ of patients who had to undergo emergency operations and 33\% had to be operated earlier than planned [75].

In conclusion, LC in acute cholecystitis is a safe procedure and favorable to OC. Early operation provides fewer readmittances and a shorter hospital stay. To quote Hunter [85] we can say 'get it while it's hot'.

\section{Current Status of Laparoscopic Therapy of Common Bile Duct Stones}

$3.6-16 \%$ of all patients undergoing cholecystectomy have CBDS [86-88]. A recent study including nearly 1,000 patients undergoing LC could show that one third of these stones pass spontaneously within 6 weeks [86]. However, we have to subdivide all patients scheduled for cholecystectomy into three groups: those with suspected CBDS preoperatively, those with intraoperative diagnosed stones and those in whom the stones are diagnosed postoperatively. Prior to the triumphant advance in laparoscopy the strategy to clear the CBD was uniformly standardized and clear. IOC was performed routinely and in case of CBDS the bile duct was revised and freed from stones $[89,90]$. ERCP was introduced in the early 1970 s [91] and gained importance after the introduction of videoendoscopy and papillotomy. The strategy of 'therapeutic splitting' is still the most accepted procedure to remove CBDS [92, 93]. However, the rising skills in laparoscopy aroused a new discussion for the best management of CBDS.

Recent studies, which will be discussed later on, have showed that single-stage treatment has become a safe and effective procedure in experienced surgeons' hands [94]. However, laparoscopic bile duct revision is still performed by a minority of surgeons. Nassar et al. [95] observed the development of CBD management over a period of 5 years in Scotland and noted that $18 \%$ of surgeons performed ERCP at the first surveillance and 14\% 5 years later. But the number of surgeons performing laparoscopic common bile duct exploration (LCBDE) also diminished from 4 to $3.8 \%$. Only $5 \%$ of surgeons rated LCBDE as their current preferred practice. In Germany the rate of LCBDE is $5.8 \%$ [96]. 
The first reports describing LCBDE arised early after the introduction of LC in the early 1990s [97, 98]. However, only 3 RCTs comparing therapeutic splitting vs. single-stage treatment are at present available.

Rhodes et al. [99] compared 40 patients either to LCBDE or to postoperative ERCP and summarized the findings that LCBDE is as effective as therapeutic splitting with one non-significant advantage of a slightly shorter hospital stay. These results are confirmed in the EAES multicenter trial [94]. The results from the third trial including 105 patients differ from the previously mentioned studies. The authors preclude ERCP in the treatment of CBDS as first-line strategy (except in cholangitis) due to a high risk of additional procedures. In their results, $29 \%$ of the ERCP group achieved additional procedures vs. $8 \%$ in the LCBDE group due to a significantly higher rate of impossibility to perform the initial procedure [100]. Finally, there are numerous cohort studies and personal series with good or excellent results published praising LCBDE as a safe and effective procedure [101-104]. The overall success rate in clearing the duct laparoscopically was $81-97 \%$, with a low morbidity of $6-13 \%$ and $4-8 \%$ retained stones.

Beside the conviction of better outcome, shorter hospital stay and the effectiveness of LCBDE, the decision to perform single-stage treatment might often be influenced by the availability of ERCP. If ERCP (which can be performed pre-, intra- and postoperatively) is established in the own team with the possibility to perform it $24 \mathrm{~h}$ a day, the surgeon might not be urged to adopt LCBDE in his strategy because the patient can be treated without any delay and lengthening of the postoperative stay. Secondly in the hands of an experienced endoscopist, ERCP is also a safe and effective procedure. CBD clearing might be up to $100 \%$ in specialized centers [105]; however, Trantner and Thompson [106] could summarize in their review an overall clearing rate from about $75 \%$. Arguments from the opponents of preoperative ERCP are the high morbidity and the high rate of 'negative ERCP'. Postinterventional pancreatitis is the most common complication. The incidence is up to $6.7 \%$ [107]. The mortality rate is variable and highly dependent on experience and technical skills. The reported mortality rate is from 0 to $2.3 \%[105,108$, 109].

High rates of avoidable ERCP as reported in series over the last decade [110] should decrease over the next decade because after the adoption of MRCP in the diagnosis of CBDS, ERCP should shift from a diagnostic to a therapeutic modality. Preoperative ERCP should be reserved for cases where CBDS are suspected [111].

So what is the current status in the treatment of CBDS? At the moment, two minimal invasive techniques are available. Preoperative ERCP is the most applied technique and therefore still the standard procedure. The laparoscopic approach is less frequently used but provides excellent results in the hands of an expert. To give a recommendation on the treatment of CBDS according to the available literature we think the algorithm suggested by the American Society for Gastrointestinal Endoscopy has a high impact and is valid to be adopted in the pathway of CBDS management [112].

\section{Spilled Gallstone}

There are 8 studies dealing with the problem of spilled gallstones with more then 500 LC. Sarli et al. [113] reported on 1,127 patients of whom a gallbladder perforation occurred in 131 patients (11.6\%). In 26 of those $(2.3 \%)$, the stones were left in the abdominal cavity. In their conclusion, two reasons are responsible for the mishap of a lost gallstone, namely the experience of the surgeon and the grade of inflammation of the gallbladder. The second study by Diez et al. [114] covers 3,686 LC. Gallstone spillage occurred in 627 patients (17\%), the stones could be removed in 214 and were left in 40 patients $(1.1 \%$ of all patients and $6.3 \%$ of patients with lost gallstone). Complications occurred in 12 patients. Woodfield et al. [115] covers the other six studies in a review. Gallbladder perforation occurred in 3,356 patients out of 18,280 undergoing LC (18.3\%) with an incidence of spillage of $7.3 \%$. However, a retrospective analysis from Switzerland could show that only $1.4 \%$ of patients with spillage of gallstones develop severe postoperative complications [116]. The list of complications is manifold, from abscess formation intra-abdominally, intracutaneously or subphrenically, to small bowel obstruction and mimicking acute appendicitis. The gap between the spillage and the occurrence of the first symptoms is wide between immediately and after 29 months, with the peak at 4 months postoperatively [117]. The biochemical composition of the stone has a high impact on the genesis of postoperative complications. Pigmented stones are usually afflicted with more septic complications than others $[118,119]$. However, once gallstones are spilled, every attempt should be made to retrieve as many as possible, but due to the low incidence of postoperative complications, a conversion to OC does not seem to be justified [116]. 


\section{Conclusion}

LC is the treatment of choice in the management of cholecystolithiasis and cholecystitis. With regard to the literature, LC offers advantages over OC in the early postoperative period concerning recovery, pain and pulmo- nary function. The long-term benefits are a better cosmetic result and a lower incidence of incisional hernias. Routine IOC is not mandatory. In case of CBDS, therapeutic splitting is still the most accepted procedure. Gastroscopy should be reserved for patients with unclear upper gastrointestinal symptoms.

\section{References}

-1 Kratzer W, Mason RA, Kachele V: Prevalence of gallstones in sonographic surveys worldwide. J Clin Ultrasound 1999;27:1-7.

-2 Zacks SL, Sandler RS, Rutledge R, Brown RS Jr: A population-based cohort study comparing laparoscopic cholecystectomy and open cholecystectomy. Am J Gastroenterol 2002;97: 334-340.

-3 Proceedings of the NIH Consensus Development Conference on Gallstones and Laparoscopic Cholecystectomy, Bethesda, Md, September 14-16, 1992. Am J Surg 1993;165: 387-548.

4 Mühe E: Die erste Cholezystektomie durch das Laparoskop. Kongressbericht 69. Langenbecks Arch Chir 1986;369:804.

$\checkmark 5$ Mouret P: From the first laparoscopic cholecystectomy to the frontiers of laparoscopic surgery: the future prospectives. Dig Surg 1991;8: 124.

6 McSherry CK: Cholecystectomy: the gold standard. Am J Surg 1989;158:174-178.

7 Shamiyeh A, Wayand W: Laparoscopic cholecystectomy: early and late complications and their treatment. Langenbecks Arch Surg 2004; 389:164-171.

$>8$ Nilsson U: Adverse reactions to iotroxate at intravenous cholangiography. A prospective clinical investigation and review of the literature. Acta Radiol 1987;28:571-575.

$\checkmark 9$ Dawson P, Adam A, Benjamin IS: Intravenous cholangiography revisited. Clin Radiol 1993; 47:223-225.

10 Lindsey I, Nottle PD, Sacharias N: Preoperative screening for common bile duct stones with infusion cholangiography: review of 1,000 patients. Ann Surg 1997;226:174-178.

11 Shamiyeh A, Rieger R, Schrenk P, Lindner E, Wayand W: Spiral CT cholangiography is not suitable for routine diagnosis before laparoscopic cholecystectomy. Chirurg 2001;72: 159-163.

- 12 Neuhaus H, Ungeheuer A, Feussner H, Classen M, Siewert JR: Laparoscopic cholecystectomy: ERCP as standard preoperative diagnostic technique. Dtsch Med Wochenschr 1992; 117:1863-1867.

13 Windhorst T, Hupe K, Wenning M: General practice-relevant conclusions based on 74,400 documented biliary surgery interventions. Zentralbl Chir 2000;125(suppl 2):218-223.
14 Thybusch A, Schaube H, Schweizer E, Goll- 26 Hasson HM: A modified instrument and methnick D, Grimm H: Significant value and therapeutic implications of routine gastroscopy before cholecystectomy. J Chir (Paris) 1996;133: $171-174$.

15 Schwenk W, Bohm B, Badke A, Zarras K, Stock W: Preoperative esophagogastroduodenoscopy before elective surgical therapy of symptomatic cholelithiasis. Leber Magen Darm 1992;22:225-229.

16 Krystyn S, Wojciech Z, Jerzy P, Tomasz S Joanna M: Gastroduodenoscopy: a routine examination of 2,800 patients before laparoscopic cholecystectomy. DOI 10.1007/s00464 004-2025-6.

17 Fahlke J, Ridwelski K, Manger T, Grote R, Lippert H: Diagnostic workup before laparoscopic cholecystectomy - which diagnostic tools should be used? Hepatogastroenterology 2001;48:59-65.

18 Beyermann K, Stinner B, Hasselmann U, Rothmund M: Consequences of routine gastroscopy before cholecystectomy. Langenbecks Arch Chir 1992;377:314-316.

19 Ure BM, Troidl H, Spangenberger W, Lefering R, Dietrich A, Sommer H: Evaluation of routine upper digestive tract endoscopy before laparoscopic cholecystectomy. Br J Surg 1992; 79:1174-1177.

20 Menes T, Spivak H: Laparoscopy: searching for the proper insufflation gas. Surg Endosc 2000; 14:1050-1056.

-21 Farley DR, Greenlee SM, Larson DR, Harrington JR: Double-blind, prospective, randomized study of warmed, humidified carbon dioxide insufflation vs. standard carbon dioxide for patients undergoing laparoscopic cholecystectomy. Arch Surg 2004;139:739-744.

22 Dubois F, Berthelot G, Levard H: Cholecystectomy by coelioscopy. Presse Méd 1989;18. 980-982.

23 Dubois F, Berthelot G, Levard H: Coelioscopic cholecystectomy: experience with 2,006 cases. World J Surg 1995; 19:748-752.

24 Köckerling F, Hohenberger W: Videoendoskopische Chirurgie. Heidelberg, Johann Ambrosius Barth, 1998.

25 Catarci M, Carlini M, Gentileschi P, Santoro $\mathrm{E}$ : Major and minor injuries during the creation of pneumoperitoneum. A multicenter study on 12,919 cases. Surg Endosc 2001;15: $566-569$. od for laparoscopy. Am J Obstet Gynecol 1971; 110:886-887.

27 Hashizume M, Sugimachi K: Needle and trocar injury during laparoscopic surgery in Japan. Surg Endosc 1997;11:1198-1201.

28 Ballem RV, Rudomanski J: Techniques of pneumoperitoneum. Surg Laparosc Endosc 1993;3:42-43.

29 Sigman HH, Fried GM, Garzon J, Hinchey EJ, Wexler MJ, Meakins JL, Barkun JS: Risks of blind versus open approach to celiotomy for laparoscopic surgery. Surg Laparosc Endosc 1993;3:296-299.

30 Strasberg SM, Hertl M, Soper NJ: An analysis of the problem of biliary injury during laparoscopic cholecystectomy. J Am Coll Surg 1995; 180:101-125.

31 Rohr S, De Manzini N, Vix J, Tiberio G, Wantz C, Meyer C: Value of absorbable clips in laparoscopic cholecystectomy. A randomized prospective study. J Chir (Paris) 1997; 134:180-184

-32 Shamiyeh A, Vattay P, Tulipan L, Schrenk P, Bogner S, Danis J, Wayand W: Closure of the cystic duct during laparoscopic cholecystectomy with a new feedback-controlled bipolar sealing system in case of biliary obstruction an experimental study in pigs. Hepatogastroenterology 2004;51:931-933.

-33 Matthews BD, Pratt BL, Backus CL, Kercher KW, Mostafa G, Lentzner A, Lipford EH, Sing RF, Heniford BT: Effectiveness of the ultrasonic coagulating shears, LigaSure vessel sealer, and surgical clip application in biliary surgery: a comparative analysis. Am Surg 2001; 67:901-906.

-34 Raj PK, Castillo G, Urban L: Laparoscopic cholecystectomy: fundus-down approach. J Laparoendosc Adv Surg Tech A 2001;11:95100 .

35 Rosenberg J, Leinskold T: Dome down laparosonic cholecystectomy. Scand J Surg 2004;93: 48-51.

36 Ichihara T, Takada M, Ajiki T, Fukumoto S, Urakawa T, Nagahata Y, Kuroda Y: Tape ligature of cystic duct and fundus-down approach for safety laparoscopic cholecystectomy: outcome of 500 patients. Hepatogastroenterology 2004;51:362-364. 
\37 Nursal TZ, Yildirim S, Tarim A, Noyan T, Poyraz P, Tuna N, Haberal M: Effect of drainage on postoperative nausea, vomiting, and pain after laparoscopic cholecystectomy. Langenbecks Arch Surg 2003;388:95-100.

>38 Hicken NF, McAllister AJ: Operative cholangiography as an aid in reducing the incidence of overlooked common bile duct stones: a study of 1,293 choledocholithotomies. Surgery 1964;55:753-758.

-39 Moosman DA, Collier FA: Prevention of traumatic injury to the bile ducts. A study of the structures of the cystohepatic angle encountered in cholecystectomy and supraduodenal choledochostomy. Am J Surg 1951;82:132143.

40 Pitkaranta P, Haapiainen R, Ovaska J, Vanttinen $\mathrm{E}$ : When is routine operative cholangiography necessary? An evaluation of 200 consecutive patients operated on for gallbladder stones. Ann Chir Gynaecol 1992;81:291-294.

-41 Amott D, Webb A, Tulloh B: Prospective comparison of routine and selective operative cholangiography. ANZ J Surg 2005;75:378-382.

42 Pietra N, Sarli L, Maccarini PU, Sabadini G, Costi R, Gobbi S: Five-year prospective audit of routine intravenous cholangiography and selective endoscopic retrograde cholangiography with or without intraoperative cholangiography in patients undergoing laparoscopic cholecystectomy. World J Surg 2000;24:345352.

43 Borjeson J, Liu SK, Jones S, Matolo NM: Selective intraoperative cholangiography during laparoscopic cholecystectomy: How selective? Am Surg 2000;66:616-618.

44 Thornton DJ, Robertson A, Alexander DJ: Laparoscopic cholecystectomy without routine operative cholangiography does not result in significant problems related to retained stones. Surg Endosc 2002; 16:592-595

45 Soper NJ, Dunnegan DL: Routine versus selective intra-operative cholangiography during laparoscopic cholecystectomy. World J Surg 1992;16:1133-1140.

-46 Nies C, Bauknecht F, Groth C, Clerici T, Bartsch D, Lange J, Rothmund M: Intraoperative cholangiography as a routine method? A prospective, controlled, randomized study. Chirurg 1997;68:892-897.

-47 Davidoff AM, Pappas TN, Murray EA, Hilleren DJ, Johnson RD, Baker ME, Newman GE, Cotton PB, Meyers WC: Mechanisms of major biliary injury during laparoscopic cholecystectomy. Ann Surg 1992;215:196-202.

-48 Wright KD, Wellwood JM: Bile duct injury during laparoscopic cholecystectomy without operative cholangiography. Br J Surg 1998;85: 191-194.

-49 Manson JM: Intraoperative cholangiography and bile duct injury in laparoscopic cholecystectomy. Surg Endosc 2000;14:94-95.

>50 Metcalfe MS, Ong T, Bruening MH, Iswariah H, Wemyss-Holden SA, Maddern GJ: Is laparoscopic intraoperative cholangiogram a matter of routine? Am J Surg 2004; 187:475-481.
Branum G, Schmitt C, Baillie J, Suhocki P, Baker M, Davidoff A, et al: Management of major biliary complications after laparoscopic cholecystectomy. Ann Surg 1993;217:532541.

52 Rossi RL, Schirmer WJ, Braasch JW, Sanders LB, Munson JL: Laparoscopic bile duct injuries. Risk factors, recognition, and repair. Arch Surg 1992; 127:596-602.

-53 Syrakos T, Antonitsis P, Zacharakis E, Takis A, Manousari A, Bakogiannis K, et al: Smallincision (mini-laparotomy) versus laparoscopic cholecystectomy: a retrospective study in a university hospital. Langenbecks Arch Surg 2004;389:172-177.

-54 Majeed AW, Troy G, Nicholl JP, Smythe A, Reed MW, Stoddard CJ, Peacock J, Johnson AG: Randomised, prospective, single-blind comparison of laparoscopic versus small-incision cholecystectomy. Lancet 1996;347:989994.

55 Trondsen E, Reiertsen O, Andersen OK, Kjærsgaard P: Laparoscopic and open cholecystectomy. A prospective, randomized study. Eur J Surg 1993; 159:217-221.

56 Ji W, Li LT, Wang ZM, Quan ZF, Chen XR, Li JS: A randomized controlled trial of laparoscopic versus open cholecystectomy in patients with cirrhotic portal hypertension. World J Gastroenterol 2005;11:2513-2517.

57 McMahon AJ, Russell IT, Ramsay G, Sunderland G, Baxter JN, Anderson JR, Galloway D, O’Dwyer PJ: Laparoscopic and minilaparotomy cholecystectomy: a randomized trial comparing postoperative pain and pulmonary function. Surgery 1994;115:533-539.

58 Berggren U, Gordh T, Grama D, Haglund U, Rastad J, Arvidsson D: Laparoscopic versus open cholecystectomy: hospitalization, sick leave, analgesia and trauma responses. $\mathrm{Br} \mathrm{J}$ Surg 1994;81:1362-1365.

59 McMahon AJ, Russell IT, Baxter JN, Ross S, Anderson JR, Morran CG, Sunderland G, Galloway D, Ramsay G, O’Dwyer PJ: Laparoscopic versus minilaparotomy cholecystectomy: a randomised trial. Lancet 1994;343:135-138.

60 Huang SM, Wu CW, Lui WY, P'eng FK: A prospective randomised study of laparoscopic vs. open cholecystectomy in aged patients with cholecystolithiasis. S Afr J Surg 1996;34:177179.

61 Hendolin HI, Paakonen ME, Alhava EM, Tarvainen $R$, Kemppinen T, Lahtinen P: Laparoscopic or open cholecystectomy: a prospective randomised trial to compare postoperative pain, pulmonary function, and stress response. Eur J Surg 2000;166:394-399.

62 Squirrell DM, Majeed AW, Troy G, Peacock JE, Nicholl JP, Johnson AG: A randomized, prospective, blinded comparison of postoperative pain, metabolic response, and perceived health after laparoscopic and small incision cholecystectomy. Surgery 1998;123:485-495.

63 Ros A, Gustafsson L, Krook H, Nordgren CE, Thorell A, Wallin G, Nilsson E: Laparoscopic cholecystectomy versus mini-laparotomy cholecystectomy: a prospective, randomized, single-blind study. Ann Surg 2001;234:741-749.
64 Livingston EH, Rege RV: A nationwide study of conversion from laparoscopic to open cholecystectomy. Am J Surg 2004;188:205-211.

65 Ludwig K, Lorenz D, Köckerling F: Surgical strategies in the laparoscopic therapy of cholecystolithiasis and common duct stones. ANZ J Surg 2002; 72:547-552.

-66 Fletcher DR, Hobbs MS, Tan P, Valinsky LJ, Hockey RL, Pikora TJ, Knuiman MW, Sheiner HJ, Edis A: Complications of cholecystectomy: risks of the laparoscopic approach and protective effects of operative cholangiography. A population-based study. Ann Surg 1999;229:449-457.

67 Friedman GD: Natural history of asymptomatic and symptomatic gallstones. Am J Surg 1993;165:399-404.

68 Wilson AK, Kozol RA, Salwen WA, Manov LJ, Tennenberg SD: Gangrenous cholecystitis in an urban VA hospital. J Surg Res 1994;56: 402-404.

69 Kiviluoto T, Siren J, Luukkonen P, Kivilaakso E: Randomised trial of laparoscopic versus open cholecystectomy for acute and gangrenous cholecystitis. Lancet 1998;351:321-325.

70 Bedirli A, Sakrak O, Sozuer EM, Kerek M, Guler I: Factors effecting the complications in the natural history of acute cholecystitis. Hepatogastroenterology 2001;48:1275-1278.

71 Indar AA, Beckingham IJ: Acute cholecystitis. BMJ 2002:21;325:639-643.

72 Khuroo MS: Ascariasis. Gastroenterol Clin North Am 1996;25:553-577.

73 Lee HK, Han HS, Min SK, Lee JH: Sex-based analysis of the outcome of laparoscopic cholecystectomy for acute cholecystitis. Br J Surg 2005;92:463-466.

74 Teoh WM, Cade RJ, Banting SW, Mackay S, Hassen AS: Percutaneous cholecystostomy in the management of acute cholecystitis. ANZ J Surg 2005;75:396-398.

75 Cameron IC, Chadwick C, Phillips J, Johnson AG: Current practice in the management of acute cholecystitis. Br J Surg 2000;87:362373.

76 Van der Linden W, Sunzel H: Early versus delayed operation for acute cholecystitis. A controlled clinical trial. Am J Surg 1970;120:713.

77 McArthur P, Cuschieri A, Sells RA, Shields R: Controlled clinical trial comparing early with interval cholecystectomy for acute cholecystitis. Br J Surg 1975;62:850-852.

78 Vetrhus M, Soreide O, Nesvik I, Sondenaa K Acute cholecystitis: delayed surgery or observation. A randomized clinical trial. Scand J Gastroenterol 2003;38:985-990.

79 Johansson M, Thune A, Nelvin L, Stiernstam M, Westman B, Lundell L: Randomized clinical trial of open versus laparoscopic cholecystectomy in the treatment of acute cholecystitis. Br J Surg 2005;92:44-49.

-80 Eldar S, Sabo E, Nash E, Abrahamson J, Matter I: Laparoscopic versus open cholecystectomy in acute cholecystitis. Surg Laparosc Endosc 1997; 7:407-414. 
81 Hsieh CH: Early minilaparoscopic cholecystectomy in patients with acute cholecystitis. Am J Surg 2003; 185:344-348.

\$82 Lai PB, Kwong KH, Leung KL, Kwok SP, Chan AC, Chung SC, Lau WY: Randomized trial of early versus delayed laparoscopic cholecystectomy for acute cholecystitis. Br J Surg 1998;85:764-767.

-83 Lo CM, Liu CL, Fan ST, Lai EC, Wong J: Prospective randomized study of early versus delayed laparoscopic cholecystectomy for acute cholecystitis. Ann Surg 1998;227:461-467.

84 Johansson M, Thune A, Blomqvist A, Nelvin L, Lundell L: Management of acute cholecystitis in the laparoscopic era: results of a prospective, randomized clinical trial. J Gastrointest Surg 2003;7:642-645.

85 Hunter JG: Acute cholecystitis revisited: get it while it's hot. Ann Surg 1998;227:468-469.

-86 Collins C, Maguire D, Ireland A, Fitzgerald E, O'Sullivan GC: A prospective study of common bile duct calculi in patients undergoing laparoscopic cholecystectomy: natural history of choledocholithiasis revisited. Ann Surg 2004;239:28-33.

- 87 Ijzermans JN, De Waard P, Merkelbach JW: Cholangiography during cholecystectomy: a plea for selective use. Neth J Surg 1989;41:7981.

88 Mark DH, Flamm CR, Aronson N: Evidencebased assessment of diagnostic modalities for common bile duct stones. Gastrointest Endosc 2002;56(suppl 6):S190-S194.

-89 Kramling HJ, Lange V, Heberer G: Current status of gallstone surgery in Germany. Results of a survey and retrospective analysis of 27,403 interventions - open vs. laparoscopic surgery. Chirurg 1993;64:295-302.

90 Pitt HA: Role of open choledochotomy in the treatment of choledocholithiasis. Am J Surg 1993;165:483-486.

91 Cotton PB: Cannulation of the papilla of Vater by endoscopy and retrograde cholangiopancreatography. Gut 1972;13:1014-1025.

-92 Huttl TP, Hrdina CH, Geiger TK, Meyer G, Schildberg FW, Kramling HJ: Management of common bile duct stones - Results of a nationwide survey with analysis of 8,433 common bile duct explorations in Germany. Zentralbl Chir 2002;127:282-289

93 Fernandez M, Csendes A, Yarmuch J, Diaz H, Silva J: Management of common bile duct stones: the state of the art in 2000. Int Surg 2003;88:159-163.

94 Cuschieri A, Lezoche E, Morino M, Croce E, Lacy A, Toouli J, Faggioni A, Ribeiro VM, Jakimowicz J, Visa J, Hanna GB: EAES multicenter prospective randomized trial comparing two-stage vs. single-stage management of patients with gallstone disease and ductal calculi. Surg Endosc 1999;13:952-957.

95 Hamouda A, Khan M, Mahmud S, Sharp CM, Nassar AHM: Management trends for suspected ductal stones in Scotland (abstract). 9th World Congress of Endoscopic Surgery, Cancun, 2004.
96 Ludwig K, Lorenz D, Köckerling F: Surgical strategies in the laparoscopic therapy of cholecystolithiasis and common duct stones. ANZ J Surg 2002;72:547-552.

-97 Sackier JM, Berci G, Paz-Partlow M: Laparoscopic trancystic choledocholithotomy as an adjunct to laparoscopic cholecystectomy. Am Surg 1991;57:323-326.

98 Petelin JB: Laparoscopic approach to common duct pathology. Surg Laparosc Endosc 1991;1:33-41.

-99 Rhodes M, Sussman L, Cohen L, Lewis MP. Randomised trial of laparoscopic exploration of common bile duct versus postoperative endoscopic retrograde cholangiography for common bile duct stones. Lancet 1998;351: 159-161.

100 Suc B, Escat J, Cherqui D, Fourtanier G, Hay JM, Fingerhut A, Millat B: Surgery vs. endoscopy as primary treatment in symptomatic patients with suspected common bile duct stones: a multicenter randomized trial. French Associations for Surgical Research. Arch Surg 1998; 133:702-708.

101 Paganini AM, Feliciotti F, Guerrieri M, Tamburini A, Beltrami E, Carlei F, Lomanto D, Campagnacci R, Nardovino M, Sottili M, Rossi C, Lezoche E: Single-stage laparoscopic surgery of cholelithiasis and choledocholithiasis in 268 unselected consecutive patients. Ann Ital Chir 2000;71:685-692.

102 Petelin JB: Laparoscopic common bile duct exploration. Surg Endosc 2003;17:17051715.

103 Ebner S, Rechner J, Beller S, Erhart K, Riegler FM, Szinicz G: Laparoscopic management of common bile duct stones. Surg Endosc 2004; 18:762-765.

104 Millat B, Atger J, Deleuze A, Briandet H, Fingerhut A, Guillon F, Marrel E, De Seguin C, Soulier P: Laparoscopic treatment for choledocholithiasis: a prospective evaluation in 247 consecutive unselected patients. Hepatogastroenterology 1997;44:28-34.

105 Sungler P, Holzinger J, Heinerman PM, Waclawiczek HW, Boeckl O: Preoperative therapeutic splitting. Zentralbl Chir 1997; 122:1083-1087.

106 Tranter SE, Thompson MH: Comparison of endoscopic sphincterotomy and laparoscopic exploration of the common bile duct. Br $\mathbf{J}$ Surg 2002;89:1495-1504.

107 Pereira-Lima JC, Rynkowski CB, Rhoden EL: Endoscopic treatment of choledocholithiasis in the era of laparoscopic cholecystectomy: prospective analysis of 386 patients. Hepatogastroenterology 2001; 48: 1271-1274.

118 Hawasli A, Schroder D, Rizzo J, Thusay M, Takach TJ, Thao U, Goncharova I: Remote complications of spilled gallstones during laparoscopic cholecystectomy: causes, prevention, and management. J Laparoendosc Adv Surg Tech A 2002;12:123-128.

-119 Gurleyik E, Gurleyik G, Yucel O, Unalmiser S: Does chemical composition have an influence on the fate of intraperitoneal gallstone in rat? Surg Laparosc Endosc 1998;8:113-116. 